\title{
Reviving fiscal policy in Europe: towards an implementation of the golden rule of public investment*
}

\author{
Achim Truger \\ Berlin School of Economics and Law, Germany
}

The implementation of a golden rule of public investment as a necessary institutional reform and an important step aimed at overcoming the constraints imposed by the new European Economic Governance are proposed. The rule is widely accepted in traditional public finance and can deliver both intergenerational fairness as well as more growth and employment. The golden rule would exempt public (net) investment suitably defined from the relevant deficit targets of both the preventative and the corrective arms of the Stability and Growth Pact as well as the Fiscal Compact. That way, fiscal policy would be upgraded and would receive more room for manoeuvre and public investment as a particularly growth-enhancing public expenditure category would be strengthened. Different definitions are discussed and a pragmatic definition based on the national accounts with some modifications will be proposed. The standard reservations against a golden rule are critically assessed and mostly discarded. Although a proper implementation would need some time, this should not be an excuse for not using pragmatic short-term solutions that are readily available at the European level.

Keywords: golden rule, public investment, fiscal policy, austerity, euro area

JEL codes: E22, E61, E62, E65, H54, H62

\section{INTRODUCTION}

As the euro crisis hit, European policy-makers reacted with austerity policies and a tightening of the Stability and Growth Pact (SGP). The failure of these policies is obvious and could have been predicted (Truger 2013): after seven years of deep economic crisis the euro area is still far away from full recovery and deflationary risks persist. Public investment, which should have stabilized the economies and kept up their long-term growth potential, has dramatically shrunk in the periphery (see Figure 1). Gross public investment in relation to GDP almost halved from more than 4 per cent before the crisis to only 2.2 per cent of GDP since 2013 in the European periphery. Net public investment, that is to say gross investment minus depreciation, decreased from about 2 per cent of GDP to -0.6 per cent of GDP: the net public capital stock in the periphery was shrinking. Fiscal policy has been completely disempowered, at the very moment when it is most needed.

* This article is based on a more comprehensive study written for the Austrian Chamber of Labour (Truger 2015a).

Received 24 October 2015, accepted 11 January 2016 


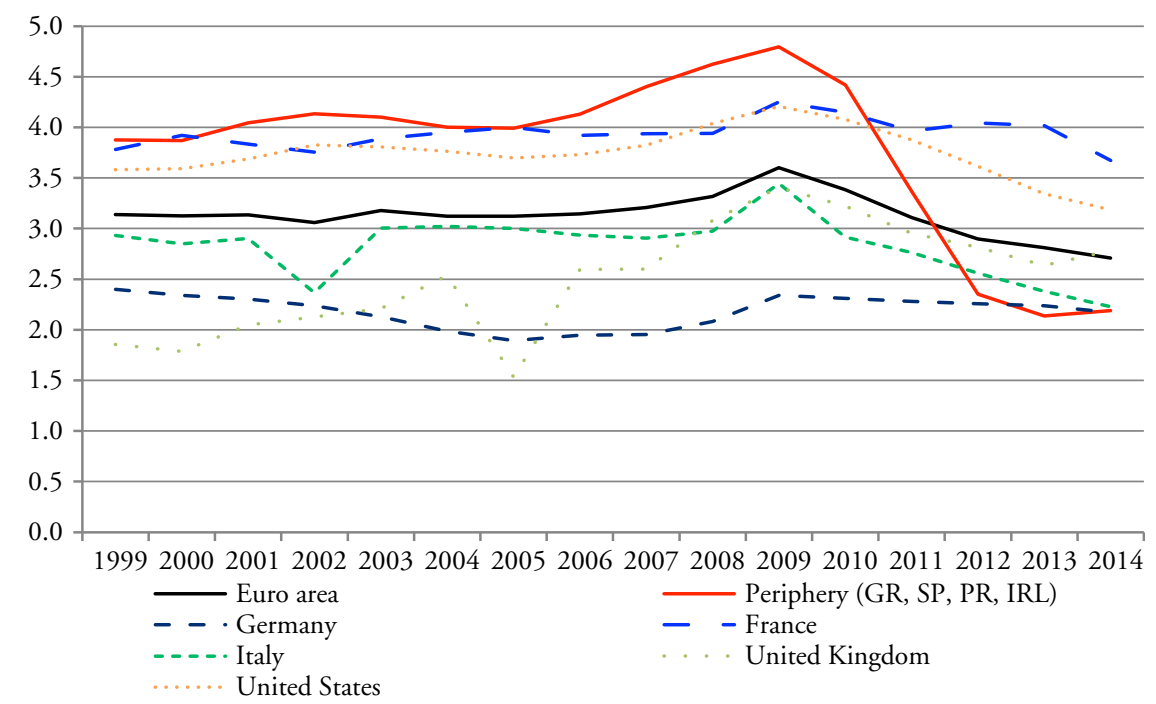

Source: European Commission (2015a); author's calculations.

Figure 1 General government gross fixed capital formation (ESA 2010) in the euro area, the European Periphery and selected countries in per cent of GDP, 1999-2014

Obviously, a different approach to fiscal policy and to supporting public investment is needed. In fact, it is by now widely accepted at the EU level that a more expansionary fiscal policy is necessary, because monetary policy alone will not spark off the recovery. In his Jackson Hole speech, Mario Draghi called for a more expansionary fiscal stance for the euro area and a public investment programme (Draghi 2014). The new European Commission has launched two initiatives, substantially enlarging its predecessor's efforts. First, an Investment Plan for Europe, the 'Juncker Plan', has been presented, that is to say a European Fund for Strategic Investments (EFSI) to finance investment on a large scale (European Commission 2014). It is difficult to evaluate the Plan's prospects as it is still in its very early stages. However, there are many open questions and whether it will really deliver is quite doubtful. Second, the interpretation of the SGP has been clarified with the aim of providing more fiscal leeway for member states under adverse economic conditions and/or implementing structural reforms (European Commission 2015b). This may slow the pace of consolidation somewhat, but will certainly not provide the necessary positive fiscal stimulus.

An approach that could really make a difference would be the so-called golden rule of public investment. The rule is widely accepted in the traditional public finance literature and would prescribe financing net public investment by government deficits, thus promoting intergenerational fairness as well as economic growth. Public investment increases the public and/or social capital stock and creates growth to the benefit of future generations. Future generations contribute to financing those investments via the debt service. Failure to allow for debt financing will lead to a disproportionate burden for the present generation via higher taxes or expenditure cuts and therefore most probably to underinvestment, which is exactly what has happened in Europe under the austerity policies. 
The EU Commission has to date strongly resisted the introduction of such a golden rule, because supposedly it would not fit into the fiscal framework of the reinforced SGP and the fiscal compact and put fiscal sustainability at risk (European Commission 2004: 132; 2012: 25). However, this is somewhat ironic: even the conservative German council of economic experts, not exactly known for an inclination towards loose budgets, had included the golden rule in its proposal for a German debt brake (SVR 2007). Hence, the original blueprint for the German debt brake - and therefore also for the Fiscal Compact at the European level - in fact included a golden rule for public investment!

Therefore, the present article presents a concrete proposal for the introduction of the golden rule of public investment in the $\mathrm{EU}$ in order to strengthen and protect public investment and to increase growth while at the same time not sacrificing fiscal sustainability. Section 2 presents an attempt to operationalize the theoretical concept of the golden rule. The basic theoretical idea and the short- as well as long-run growth effects of traditional public investment are presented. Definitions of public investment different from the standard one from the national accounts are discussed. Section 3 is preoccupied with the question of implementing the golden investment rule in the present European fiscal policy framework. Section 4 briefly concludes.

\section{THE GOLDEN RULE: FROM THEORY TO OPERATIONALIZATION}

\subsection{Theoretical aspects: the pay-as-you-use principle and intergenerational equity}

The 'golden rule' has been a widely accepted traditional public finance concept for the handling of government deficits for decades (see Musgrave 1939; 1959: 556-575). ${ }^{1}$ It strives for an intertemporal realization of the pay-as-you-use principle in the case that present government spending provides future benefits. It allows financing of such spending ( $=$ net public investment) by government deficits, thus promoting intergenerational equity. Net public investment increases the public and/or social capital stock and provides benefits for future generations. Therefore, it is justified that future generations contribute to financing those investments via the debt service. Future generations inherit the burden of public debt, but in exchange they receive a corresponding public and/or social capital stock. Failure to allow for debt financing of future generations' benefits will lead to a disproportionate burden for the present generation through higher taxes or lower spending, creating incentives for the underprovision of public investment to the detriment of future generations. This general incentive problem may become exacerbated in times of fiscal consolidation when cutting public investment may seem the politically easiest way of reducing the budget deficit. The recent experience with austerity policies shows that this danger is real. Independently of the current crisis, there is evidence that fiscal contractions were a key factor responsible for the decline in public investment in earlier decades (Turrini 2004: 9-26; Välilä/Mehrotra 2005).

Although the general idea behind the golden rule is plausible, its operationalization is difficult. The most difficult problem is to find a workable and economically sensible definition of the term 'public investment' that allows for government deficits. Theoretically, any government action that creates benefits - in the widest sense - for more than one

1. It should be mentioned that the golden rule is difficult to justify from a traditionally Keynesian or post-Keynesian functional finance view: although it would be seen as a major step forward if compared to balanced budget or similar approaches to budget deficits, investment expenditure as an upper limit to government deficits would usually be considered as an arbitrary and probably tootight constraint for fiscal policy. See for example Sawyer (2009) and Mathieu/Sterdyniak (2012). 
period may qualify for this. However, the literature usually focuses on concrete future material economic benefits in terms of higher productivity and growth. The question for an individual potential investment project then becomes whether it creates enough public and/or social capital that its returns are higher than or at least equal to its costs in terms of interest payments and possibly additional costs. Ideally, if the returns are high enough, debt sustainability would automatically be satisfied as the additional growth would decrease or at least stabilize the debt-to-GDP ratio (IMF 2014: 110). The optimal approach of defining public investment that qualifies for deficit finance would then be to include all public spending projects that create sufficient returns in terms of higher future productivity and growth. Obviously, such a classification process would be extremely costly and unfeasible in practice. Therefore, the central question on a macroeconomic level is whether general categories of public spending can be identified that are usually associated with sufficiently higher growth and productivity. Of course, such a pragmatic approach necessarily risks including types of public spending that should not be qualified as investment as well as excluding types of public spending that should correctly be classified as investment.

However, despite the difficult questions from a theoretical point of view that strives for optimality, the concept of the golden rule has many advocates in academia starting with Richard A. Musgrave (1939; 1959), one of the founding fathers of modern public finance. In the context of the fiscal policy debate in the $\mathrm{EU}$, many economists have criticized the EU fiscal framework of the SGP for its lack of a golden rule of public investment and have correspondingly proposed to introduce such a rule into the framework (for example, Fitoussi/Creel 2002: 63-65; Blanchard/Giavazzi 2004; Barbiero/Darvas 2014; Dervis/ Saraceno 2014). And, last but not least, the German council of economic experts delivered a proposal as early as 2007 that was to become more or less the blueprint for the German debt brake, which explicitly expressed the need to include the golden rule as an important element of the fiscal rule (SVR 2007).

\section{2 (Traditional) public investment and economic performance}

Obviously one crucial question for the justification of the golden investment rule is whether public investment is productive - that is, whether it increases productivity and growth. The long-run growth effects of public investment have therefore received much attention in the literature (see Romp/de Haan 2005; Melo et al. 2013; Bom/Ligthart 2014). From a theoretical point of view it is most plausible that public investment, especially if it focuses on 'core' infrastructure like transport facilities (roads, railways, ports, airports) and communication systems, as well as power generation and other utilities, should be productive and growth-enhancing. The public infrastructure stock in this sense is simply indispensable for most productive processes: without water and energy supply, and without transport capacities, most production processes would simply be unthinkable. It is, therefore, plausible to think of public infrastructure as an input factor that is complementary to private capital and labour inducing additional private investment and labour supply.

However, at least two qualifications should be made. First, for additional public infrastructure to be productive it should not be abundant. Although the quantity and quality of infrastructure is difficult to measure, on the basis of the World Economic Forum's Competitiveness report the IMF (2014: 79-81) concludes that the overall quality of infrastructure and of roads has clearly (slightly) decreased from 2006 to 2012 in Germany (France) and that it is lagging behind in Italy. This is at least a hint that there is room for improvement. It is also a hint that net public investment must not necessarily be 
put into completely new infrastructure projects, but that maintenance investment may also have an important role to play. Second, although positive growth effects from core infrastructure investment are most plausible from a theoretical point of view, not all of public investment as defined in the national accounts is put into core infrastructure. In fact, a substantial part of public investment is put into equipment as well as public buildings, for example for administration, education and hospitals. For such investment, a direct positive contribution to private production processes may be more difficult to establish. However, for those countries for which data on both the public capital stock as a whole as well as specifically on public infrastructure are available, the correlation between the two is strong, so that overall public investment may serve as a proxy for infrastructure investment (IMF 2014: 80).

Empirically, as usual in economics, the effects are contested in the literature. The famous study by Aschauer (1989), using a production function approach, found a very high elasticity of output with respect to the public capital stock. This would have meant an extremely high return on public investment, indeed, much higher than imaginable for private investment. In the following debate many different definitions of public (infrastructure) capital were used, and different estimation techniques and variations of Aschauer's original approach were introduced. Furthermore, apart from Aschauer's original production function approach, the cost-function approach, times series analysis and cross section estimations were also applied. Although the results differed very much and some studies found no or even negative effects of public investment on growth, the general conclusion is that there is a positive growth effect, but that it is much smaller than originally claimed by Aschauer (see Romp/de Haan 2005; Melo et al. 2013).

Bom/Ligthart (2014) conducted meta-regressions including 68 studies with 578 estimates for the public capital-growth nexus and confirm this basic conclusion for the period 1983 to 2008. According to their results, the average output elasticity of public capital is 0.082. Conditional elasticities vary depending on whether they refer to the short or the long run, to all public capital or core infrastructure and to regional or national investment. They are higher for core infrastructure, for regional investment and for the long run. Table 1 shows the implied marginal returns which are in the range between 10 per cent (short run, national, all public capital) to 34.6 per cent (long run, regional, core infrastructure). Whereas the latter marginal return is large enough to justify deficit-financed public investment even under pessimistic assumptions about the user cost of capital (real interest rate plus depreciation rate), the former would have to rely on more favourable conditions. However, the implied long-term marginal returns, even in the case of all public capital for national and regional investment with 20.8 and 28 per cent, are considerably high. All in all, therefore, one may safely assume traditional public investment to have considerably positive long-run growth effects.

In addition to the more long-run supply-side effects, the more short-run demand-side effects of public investment must also be addressed. The analysis proceeds in two steps.

Table 1 Implied marginal returns to public investment in per cent

\begin{tabular}{lccccc}
\hline & \multicolumn{2}{c}{ All public capital } & & \multicolumn{2}{c}{ Core public capital } \\
\cline { 2 - 3 } \cline { 6 - 6 } & Regional & National & & Regional & National \\
\hline Short term & 17.4 & 10.2 & & 24.0 & 16.8 \\
Long term & 28.0 & 20.8 & & 34.6 & 27.4 \\
\hline
\end{tabular}

Source: IMF (2014: 86); Bom/Ligthart (2014: 907-908); author's calculations. 
In the first step the question of fiscal policy effectiveness as such, irrespective of the particular instrument, must be clarified, before in the second step the comparative effectiveness of the different instruments, that is to say different expenditure or revenue side categories, can be addressed.

As to fiscal policy effectiveness, the traditional precrisis empirical studies usually found positive multipliers. As suggested by the standard Keynesian textbook models and the Haavelmo theorem, expenditure multipliers were typically substantially larger than revenue-side ones (see for example the overviews by Hemming et al. 2002; Arestis/Sawyer 2003; Bouthevillain et al. 2009). Many of the more recent studies confirm the earlier multiplier estimates and in many cases even go substantially beyond them (Gechert/ Rannenberg 2014; Gechert 2015). As to the question of the relative size of the public investment multiplier, the precrisis literature as a rule of thumb found it to be (slightly) above one and therefore slightly larger than for other spending categories so that public investment, in addition to its long-term economic advantages, could be seen as the most effective short-run fiscal policy instrument. Some of the recent studies even come up with much larger (relative) estimates of the investment multiplier. Auerbach/Gorodnichenko (2013) obtain values larger than two with a maximum estimate of larger than four whereas the estimates for government consumption spending are 'only' at about 1.4 .

Based on this result, Barbiero/Darvas (2014: 8-9) conclude that a more growthfriendly consolidation in the euro area would have been possible if public investment spending had been preserved at the cost of cutting current spending. However, this conclusion does not seem fully convincing: while it is plausible to preserve public investment it is not clear whether cutting government consumption is the relevant and sensible alternative. First, although the multiplier estimate for consumption spending referred to is smaller than the investment multiplier, it is still substantially larger than one, so the damage from austerity policies would still have been very large even under the more 'growth-friendly' strategy. Second, judgment should be based on a broad overview of different studies. Gechert/Rannenberg (2014) and Gechert (2015) conducted meta-regressions respectively including 98 and 104 empirical multiplier studies controlling for different study characteristics. They also generally find higher investment multipliers as compared to their consumption counterparts (around 1.6 vs 1), but the difference is certainly not as large as in the Auerbach/Gorodnichenko (2013) paper. Third, in the case that fiscal restriction is unavoidable, the whole set of available instruments should be taken into account. This leads to the conclusion that on average cutting government spending is unnecessarily painful, because the average estimates of the revenue-side multiplier are much lower than those for the consumption or overall government spending multiplier. On average Gechert/Rannenberg (2014) and Gechert (2015) also find systematically smaller multipliers for government transfers.

This should, however, not serve as an argument for cutting social transfers for consolidation purposes: apart from the highly problematic social impact, there is evidence that the transfer multiplier is particularly high during recessions (Gechert/Rannenberg 2014). Therefore, a much more growth-friendly consolidation could be achieved via tax increases, which - from a standard Keynesian perspective - should mainly focus on high incomes and wealth. An even more growth-friendly consolidation could be achieved by spending part of the additional revenue from suitable tax increases on increased public investment or other expenditures.

All in all, therefore, the empirical literature on the short-run effects of fiscal policy strongly supports protecting public investment from consolidation pressures and using it to stimulate the economy. However, the substantial demand-side effects of other spending categories, particularly government consumption, should not be neglected either. 


\subsection{Towards an economically plausible operationalization of public investment}

Some thoughts are necessary about whether the traditional concept of investment in the national accounts is fully adequate or whether some modifications seem necessary. One important thing to notice in this context is that the definition of (public) investment has changed in the recent general revision of the system of national accounts and the transition from the old system, ESA 1995, to the new one, ESA 2010 (see Dunn et al. 2014). In general the transition to ESA 2010 and the accompanying further changes have led to an increase in gross public investment with marked differences between the countries. For net investment on average the changes are small as the increases in gross investment have almost completely been compensated for by correspondingly higher depreciation.

A first change has to do with spending on research and development. Whereas, before the revision, mostly tangible assets (construction and equipment) and a small fraction of intangible assets were counted as investment, after the revision spending on research and development was also included. From an economic point of view this seems justified as it is highly plausible that public R\&D spending in research institutions or universities or also as grants given to the business sector may be productive, although there is no clear evidence yet as to the growth effects. In addition, public R\&D spending suffered under the strong fiscal contraction (see Veugeleers 2014). This change should be the most important, quantitatively, in explaining the increase in gross investment for many countries.

A second change is highly problematic: military spending on weapons systems is now counted as fixed investment, the reason being that 'the new system recognises their productive potential for the external security of a country, over several years' (Dunn et al. 2014: 10). However, this classification can be criticized on ethical grounds: weapons systems are potentially destructive and, if really used, they destroy productive capital instead of increasing it. Indeed, that was precisely the reason why they were previously recorded as immediately consumed under ESA 1995. Furthermore, it is highly questionable whether the fiscal framework should actively encourage military spending and a potential arms race. The ethical questions apart, spending on weapons systems can hardly be considered as a particularly growthenhancing expenditure category. Theoretically, it is not clear how the marginal contribution of military investment to national security should be measured. Indeed, military investment was explicitly excluded from many studies on the long-term growth effects of public investment. Aschauer's original contribution did not find military spending to be important for economic productivity (Aschauer 1989).

A third change occurred in the delimitation of the government and the private sector. The classification has become stricter in most cases in the sense that some companies/non-profit organizations closely related to the public sector had to be reclassified from the private to the government sector. This statistical enlargement of the government sector may partly remove one shortcoming of the investment definition in the national accounts: investment grants paid by the public sector to private companies are not classified as investment expenditure. In the case that a formerly private company which receives investment grants increasing its investment expenditures is reclassified to be part of the public sector, the additional investment spending will now be counted as government investment. However, if a public investment grant is spent on investment by a recipient company then from an economic point of view it should generally not make a difference whether the company is classified as public or private. Therefore, for purposes of the golden rule, investment grants paid from the public to the private sector should be classified as public investment.

Of course, there may be other expenditure categories that are equally or even more beneficial. A natural candidate is public spending on education or health care, which in 
the existing system of national accounts is classified as current expenditure. It has been argued that privileging traditional, mostly physical investment in infrastructure and equipment and neglecting those other forms of investment in an economic sense may distort the optimal allocation of resources with potentially unclear implications for efficiency, growth and welfare (Turrini 2004: 29-30). However, in the presence of strong evidence for considerably positive growth effects of traditional public investment it would seem overcautious to forego the advantages of the golden rule. Indeed, a stepwise approach is much more convincing. The economic case for including other types of spending in the golden rule should be checked. If inclusion seems rational but at the current stage difficult to implement for statistical or other reasons, then the golden rule should as a first step be applied to traditional investment. As soon as the open questions with respect to other expenditure categories are solved, their implementation can follow as a second step.

Should other potentially growth-enhancing types of government spending be classified as investment? In principle they should, as long as it can be shown that the growth effect to be expected is at least as large as that of traditional public investment. The natural candidate for this would be education expenditure. Education as investment in human capital is crucial within endogenous growth theory (Lucas 1988) and empirical research suggests that the private as well as social rate of return of education can be assumed to be very high (Card 2001; Psacharopoulos/Patrinos 2004). Although it is difficult to reliably compare the estimated rate of return for different types of expenditure, it would at least be plausible to include public education expenditures under the golden rule. This is also the general conclusion drawn by most advocates of the golden rule.

However, at the present stage it is difficult to implement this in a convincing way. First, an exact definition of the relevant education expenditure would have to be given, which is not straightforward. Second, in order to be consistent with the golden rule, net education investment would have to be measured; that is, depreciation would have to be deducted. According to the SVR (2007: 80-81) based on Ewerhart (2002; 2003), depreciation of German human capital stock, relevant for such a calculation, would be in the order of magnitude of 95 per cent of total education spending. This particular result stems from the demographic development in Germany and must not necessarily be a very plausible way of quantifying depreciation of human capital investment. But it shows that there are some difficult conceptual issues that would have to be resolved before education expenditure could be properly included in the golden rule.

There are other expenditure categories that might be considered as investment under the golden rule. Indeed, from a supply-side perspective, some types of social spending may well be highly productive, because they increase labour supply and production: health expenditures, if effective, will contribute to a more stable and larger workforce. Spending on child care can substantially increase parents' labour force participation (Bauernschuster/Schlotter 2015). And the same may be said for spending on social work and integration. All of this could lead to higher labour force participation and therefore contribute to higher growth and, at the same time, to one of the main Europe 2020 goals. Obviously, it is not easy to find adequate definitions, and estimating depreciation in order to arrive at net investment may be even more difficult.

The fact that at the current stage there are difficulties, however, does not mean that an economically rational and workable definition of potentially relevant other investment expenditures does not exist at all. It only means that for the first stage of introducing the golden rule one would be better off relying on the traditional definition of public investment from the national accounts. 


\subsection{Some technical questions of implementation}

Even if - for practical reasons - the golden rule were initially limited to traditional public investment, some technical questions of implementation would have to be resolved. The prescriptions for the government in terms of the national accounts would have to be operationalized in terms of standard financial government accounts. This usually involves correcting for privatization revenues, loans and investment grants between government units (SVR 2007: 76). However, for the general government this is a procedure that is familiar also in the current fiscal framework in which all national governments have to regularly submit their stability programmes according to the definitions of the system of national accounts. Problems might arise for the subnational levels of government, particularly for budgetary planning at the local level in which the new conventions would most probably have to be newly implemented.

Furthermore, depending on the design of the existing systems of fiscal federalism in the member states, questions as to the vertical and horizontal allocation of the general government investment deficit allowance among and on the different federal levels may occur. For example, if the municipal level is the main investor and a substantial part of its investment is currently financed through own resources, then the implied deficit and debt ratios for the municipalities under the golden rule may become very large or collide with existing national deficit constraints for the subnational levels. Obviously this problem could be tackled by suitable investment grants from higher federal levels, which would then also be allocated the corresponding deficit allowance. The golden rule may in the medium term actually be used for an investment-friendly reform of fiscal federalism.

Another problem that has always been stressed in the discussion about the golden rule (for example, Turrini 2004: 5-6) is the estimation of depreciation that is necessary to determine net investment, that is, gross investment net of depreciation. In the absence of dual accounting in the government financial budgetary accounting systems these have to be estimated for the different federal entities. Due to lack of data, for the subnational levels this may require some less than perfect but workable technical conventions, especially for calculating and distributing depreciation between subnational governments. However, the German council of economic experts in his golden rule proposal recommended merging financial accounts and national accounts as a pragmatic solution in the absence of dual accounting. Values for gross investment could be taken from the financial accounts and values for depreciation from the national accounts. Depreciation could then be distributed to the different federal states according to its share in gross investment (SVR 2007: 77). If the technical difficulties of estimating depreciation are assessed to be overwhelming, as an alternative, a certain percentage of gross public investment (for example, in the range of 20 per cent to 50 per cent) could be used as a proxy of net investment.

After all, one should not exaggerate the conceptual and technical problems of implementing the golden rule. It should be kept in mind that the current fiscal framework in the EU relies to a large extent on complex non-observable concepts that are constantly under revision, such as the output gap and the cyclically adjusted budget balance (Barbiero/Darvas 2014: 10). This was also decidedly the position of the German council of economic experts when defending his concept for the golden rule:

Despite these limitations it would be an exaggeration to completely discard the golden rule with recourse to the inconveniences of reality. Investment-related borrowing may meet the requirements of the golden rule but in an imperfect manner so that a really convincing concept cannot be realized in its pure form. However, a complete ban of investment-related borrowing cannot even be underpinned by a theoretically plausible argument. (SVR 2007: 80; author's translation) 


\section{IMPLEMENTING THE GOLDEN RULE IN THE EUROPEAN FISCAL FRAMEWORK}

\subsection{A pragmatic proposal for a European golden investment rule}

A pragmatic first step towards the golden rule is that it should apply for government fixed capital formation as defined in the national accounts with small modifications: military spending on weapons systems should not count as investment, whereas public investment grants to firms or non-profit organizations should be counted. The rule should apply to net investment; that is, depreciation should be deducted for the rule to properly measure increases in the net public capital stock.

The golden rule could then be applied within the current fiscal framework of the SGP and the fiscal compact by deducting net public investment as defined above from member states' relevant deficit measures, that is, from the government deficit under the corrective arm and the structural deficit under the preventive arm of the pact and the fiscal compact. In effect, this means that the threshold for an excessive deficit as well as the medium-term budgetary objective would be increased by the amount of net public investment. In order to prevent a conflict between the golden rule of public investment and the goal of stabilizing public debt below 60 per cent of GDP, an upper limit for deductible net investment spending could be set at 1 or 1.5 per cent of GDP. ${ }^{2}$

Conceptual advantages apart, the focus on net investment has the further advantage of providing a strong incentive for those governments that are currently providing negative net public investment - that is, whose public capital stock is decreasing - because compared to the status quo their fiscal constraints would otherwise tighten. Although this is a welcome incentive in the medium term, countries should in the short term be given some time to adjust their net investment.

The Commission and member states should over the medium term actively promote ways of improving the statistical measurement of public investment and of improving the government accounts, in particular as concerns the calculation of depreciation. Furthermore, research and debate should also be directed towards identifying other expenditure categories that could qualify as public investment and, where applicable, towards how to include them under the golden investment rule.

\subsection{Solid implementation of the golden rule in the medium term}

One essential question is whether the introduction of the golden rule proposed here would be compatible with current EU law or whether a change of Council regulations or the Treaty would be necessary. With respect to the old Treaty, Blanchard/Giavazzi (2004: 15) argued that the old Art. 104.3 would have allowed implementing the golden rule without any treaty changes by changing the corresponding Council regulations, because it stated that in the report to be prepared by the Commission it should also be taken into account whether the government deficit exceeded government investment expenditure. However, since 2008 Art. 2 (3) of Protocol No 12 about the excessive deficit

2. The limit might not be set as a threshold above which all net investment will be fully relevant for the public deficit but rather as a limit to the percentage of net investment that is deductible from the deficit measures in order to provide incentives for public investment as a whole and prevent the category as a whole from cuts. This may seem like a rather academic question given the fact that most member states' net investment was typically below 1.5 per cent of GDP even before the crisis, however it might gain relevance if a gross definition of public investment would have to be used for the golden rule or if additional expenditure categories would be classified as public investment. 
procedure annexed to the Treaty states that investment is to be understood as gross investment. Therefore a permanent interpretation as net investment would probably be difficult to justify. In the end, this is a juridical question that is difficult to answer from an economist's point of view. The change of the Council regulation deemed necessary, however, would still require unanimous consent within the Council.

For some time, however, the introduction of the golden rule for public investment could probably be approximated even without any changes in the current institutional framework, if the European Commission and the European Council were willing to more actively use the interpretational leeway within this framework (see Table 2 for an overview of measures). Actually, the clarification as to the interpretation of the Pact that the Commission has just given can already be seen as illustrating steps in that direction (European Commission 2015b).

Additional net investment could at least be justified if it came in the form of a temporary investment programme, analogous to the way the Commission interprets contributions to the EFSI. Additionally or alternatively, it may be possible to treat an investment programme as structural reform that temporarily allows for deviations from the medium-term objective or the adjustment path towards it. As to the investment clause', it should be possible to implement it as a 'small-scale golden rule' under these conditions. Reference to adverse cyclical conditions might help to increase leeway even further, although this could create the danger of a stop-and-go investment policy, if cyclical conditions improve as can be expected under an investment programme. Finally, recourse to the exceptional clause of a severe downturn in the euro area or the EU could be had in order to justify slowing down the consolidation path and allowing for

Table 2 Ten opportunities to strengthen investment and facilitate an expansionary overall fiscal policy stance in Europe

Goals Measures

Short term (use interpretational leeway within present framework to come close to the golden rule of public investment)

Strengthening investment + Expan- (1) More active use of the 'investment clause'

sionary overall fiscal policy stance (2) Allow for temporary investment programmes (analogous to EFSI)

(3) Interpret temporary investment programmes as structural reforms

(4) Incorporate realistic investment multiplier in budgetary analysis ex-ante

(5) Use leeway in economically bad times

(6) Implement better methods of cyclical adjustment

(7) Temporarily higher spending with a view to Europe 2020 goals

(8) Use exception for severe downturn in EU or euro area

Medium term (solid implementation of the golden rule of public investment)

EU implementation

National implementation
(9) 'Investment protocol' as annex to the Treaty (simplified revisions procedure Art. 48)

(10) Change national legislation where necessary

Source: Author's compilation based on Truger (2015a). 
additional investment spending. All of this could further be supported if realistically high multiplier values were used in assessing the budgetary impact of additional investment, which may not be significantly negative or even positive. Reconsideration of the EU Commission's method of cyclical adjustment - for example, to be more in line with the OECD method and results - may create further leeway as it might increase the cyclical part of the budget deficit, thus reducing the structural deficit (Truger 2015b).

Some or all of the aforementioned interpretational leeway could be used to push up public investment to the level that would be consistent with a golden rule in the medium term. However, the permanent recourse to exceptional circumstances which would be necessary to permit permanent use of the rule for public investment in general would probably overstretch the interpretational leeway inherent in the current framework. Therefore, in order to solidly implement the golden rule at the EU level, a permanent change in the institutional fiscal framework would be adequate and probably also necessary from a legal perspective.

Such a change could be adopted as primary law in the form of an 'Investment Protocol' that would be annexed to the Treaty under the simplified revisions procedure of Art. 48 of the Lisbon treaty (see Table 2). At the member states' level, further legal changes would be required if following the fiscal compact there were other legal provisions put in place that would prevent a reinterpretation of the budget balance as net of net spending on public investment. $^{3}$

\subsection{A European Investment Programme and an expansionary overall fiscal stance to spark off the recovery}

The implementation of the golden rule of investment would probably take some time until the necessary political and legal steps could be completed. It should therefore mainly be seen as a fiscal policy framework focused on safeguarding public investment in the medium term, and not so much as a readily available instrument for providing the urgently needed - boost to the European economy in the short run. Because the Juncker Plan will not be able to provide this boost in the short run - and most probably not even in the long run - the golden rule would have to be complemented by other forms of shortterm fiscal stimulus.

As argued in the previous section, the leeway inherent in the current institutional framework is sufficiently large to permit such a stimulus. Probably the most convincing way to do this would be to use the provision concerning a severe downturn in the euro area or the EU to justify a temporary deviation from the consolidation path, thus allowing for a substantial European Investment Programme (see Table 2). The Commission has explicitly made a comparison with the 2008 European Economic Recovery Plan (European Commission 2008) to give an example of the potential use of this provision (European Commission 2015b: 17). As a condition for the use of this provision, it 'should remain limited to exceptional, carefully circumscribed situations to minimise the risk of moral hazard' (ibid.: 17). Actually, one may well argue that the euro area is presently in exactly such an exceptional situation after years of recession and stagnation and low inflation while monetary policy is at the lower bound.

Such a European Investment Programme should provide an annual stimulus of at least 1 per cent of GDP for 2 or 3 years. One option for the direction of the programme would

3. See Burret/Schnellenbach (2014) for an overview of the state of implementation of the fiscal compact in the different signatory member states. 
be to use it in order to start phasing in traditional net public investment up to the desired level after the final implementation of the golden rule. Alternatively or additionally such a programme could also be used to allow for investment needs beyond the narrow national accounts definition to contribute to public investment in a broader sense. ${ }^{4}$ Such a direction would meet concerns that the golden rule alone would only promote traditional tangible investment and neglect other important forms of investment in the economic sense of the word. This could be investment in education, including child care, but it could more generally focus on spending with a view to achieving the currently neglected Europe 2020 goals such as social inclusion or other areas that have strongly suffered under austerity for the last few years. Last but not least, the fiscal stimulus provided should not be thwarted by cutting other public expenditure. Instead, the leeway within the current institutions should be actively used to provide a substantial fiscal stimulus to the European Economy.

\section{CONCLUSION}

Most parts of the euro area have seen 7 years of deep economic crisis. Public investment which should have stabilized the economies and kept up their long-term growth potential has instead dramatically shrunk in the crisis-ridden countries of the periphery. The EU needs to address these problems. The previous strategy of tightening the fiscal constraints of the SGP has driven many member states into crisis and disempowered national fiscal policy as a macroeconomic policy instrument. Unfortunately, in the current situation, with depressed aggregate demand, deflationary tendencies and monetary policy at the lower bound, national fiscal policy is the only instrument left that could bring about a sustained recovery. The EU Commission shies away from this conclusion and tries to evade anything that might change the present institutional framework for fiscal policy.

In contrast, the golden rule of public investment accompanied by an additional fiscal boost at the start could be important elements of an alternative strategy to reform European fiscal institutions in order to boost the economy and to strengthen and protect public investment. All it would need is the will to be a bit more consequent in using the leeway provided by the current framework in the short term. And in the medium term, a small reform of the institutions would be necessary to allow the implementation of the golden rule of public investment as a widely respected traditional guideline of public finance.

It is to be hoped that it will not take further years of stagnation and more millions of unemployed before European policy-makers draw the right conclusions and start reviving fiscal policy.

4. Aiginger (2014) has made a similar proposal which he called the 'silver rule' proposal. Whereas the golden rule allows permanent debt financing of all net investment, the silver rule allows temporary debt financing of additional investment. 


\section{REFERENCES}

Aiginger, K. (2014): A silver bullet for restarting growth in Europe, http://EurActiv.com PLC, URL: http://www.euractiv.com/sections/euro-finance/silver-bullet-restarting-growth-europe-310912.

Arestis, P., Sawyer, M. (2003): Reinventing fiscal policy, in: Journal of Post Keynesian Economics, 26(1), 3-25.

Aschauer, D.A. (1989): Is public expenditure productive?, in: Journal of Monetary Economics, 23, 177-200.

Auerbach, A.J., Gorodnichenko, Y. (2013): Fiscal multipliers in recession and expansion, in: Alesina, A., Giavazzi, F. (eds), Fiscal Policy after the Financial Crisis, Chicago: University of Chicago Press, 63-98.

Barbiero, F., Darvas, Z. (2014): In sickness and in health: protecting and supporting public investment in europe, Bruegel Policy Contribution 02/2014.

Bauernschuster, S., Schlotter, M. (2015): Public child care and mothers' labor supply: evidence from two quasi-experiments, in: Journal of Public Economics, 123(1), 1-16.

Blanchard, O., Giavazzi, F. (2004): Improving the SGP through a proper accounting of public investment, CEPR Discussion Papers 4220.

Bom, P., Ligthart, J. (2014): What have we learned from three decades of research on the productivity of public capital?, in: Journal of Economic Surveys, 28(5), 889-916.

Bouthevillain, C., Caruana, J., Checherita, C., Cunha, J., Gordo, E., Haroutunian, S., Langenus, G., Hubic, A., Manzke, B., Pérez, J.J., Tommasino, P. (2009): Pros and cons of various fiscal measures to stimulate the economy, Banco de Espana Economic Bulletin, July, 123-144.

Burret, H., Schnellenbach, J. (2014): Implementation of the fiscal compact in the euro area member states, Working Paper 8/2013, updated January 2014, Wiesbaden: Sachverständigenrat zur Begutachtung der gesamtwirtschaftlichen Entwicklung.

Card, D. (2001): Estimating the return to schooling: progress on some persistent econometric problems, in: Econometrica, 69(5), 1127-1160.

Dervis, K., Saraceno, F. (2014): An investment new deal for Europe, Brookings Up Front, 3 September, URL: http://www.brookings.edu/blogs/up-front/posts/2014/09/03-european-central-bank-dervis.

Draghi, M. (2014): Unemployment in the euro area, Speech by Mario Draghi, President of the ECB, Annual central bank symposium in Jackson Hole, 22 August, URL: http://www.ecb. europa.eu/press/key/date/2014/html/sp140822.en.html.

Dunn, M., Akritidis, L., Biedman, L. (2014): The impact of ESA 2010 on key indicators of the national accounts in Europe, Eurostat Review on National Accounts and Macroeconomic Indicators, 2/2014, 7-27.

European Commission (2004): Public finances in EMU 2004, European Economy No 3, Brussels: European Commission, Directorate-General for Economic and Financial Affairs.

European Commission (2008): Communication from the Commission to the European Council: A European economic recovery plan, Brussels, 26.11.2008 COM(2008) 800 final.

European Commission (2012): A blueprint for a deep and genuine economic and monetary union: launching a European debate, COM (2012) 777 final/2.

European Commission (2014): Communication from the Commission to the European Parliament, the Council, the European Central Bank, the Economic and Social Committee, the Committee of the Regions and the European Investment Bank: An investment plan for Europe, Brussels, 26.11.2014, $\operatorname{COM}(2014) 903$ final.

European Commission (2015a): Annual macro-economic database (Ameco), February.

European Commission (2015b): Communication from the Commission to the European Parliament, the Council, the European Central Bank, the Economic and Social Committee, the Committee of the Regions and the European Investment Bank: Making the best use of the flexibility within the existing rules of the Stability and Growth Pact, Strasbourg, 13.1.2015 COM(2015) 12 final.

Ewerhart, G. (2002): Bildungsinvestitionen, brutto und netto: eine makroökonomische perspektive, in: Hartard, S., Stahmer, C. (eds), Magische Dreiecke: Berichte für eine nachhaltige Gesellschaft, Bd. 3 - Sozio-ökonomische Berichtssysteme, Marburg: Metropolis, 217-246. 
Ewerhart, G. (2003): Ausreichende Bildungsinvestitionen in Deutschland? Bildungsinvestitionen und Bildungsvermögen in Deutschland 1992-1999, Beiträge zur Arbeitsmarkt- und Berufsforschung, Nr 266, Nürnberg: Institut für Arbeitsmarkt- und Berufsforschung.

Fitoussi, J.-P., Creel, J. (2002): How to Reform the European Central Bank?, London: Centre for European Reform.

Gechert, S. (2015): What fiscal policy is most effective? A meta-regression analysis, in: Oxford Economic Papers, 67(3), 553-580.

Gechert, S., Rannenberg, A. (2014): Are fiscal multipliers regime-dependent? A meta regression analysis, IMK Working Paper No 139, September, Düsseldorf: IMK in der Hans-Böckler-Stiftung.

Hemming, R., Kell, M., Mahfouz, S. (2002): The effectiveness of fiscal policy in stimulating economic activity: a review of the literature, International Monetary Fund Working Paper No 02/ 208, Washington, DC.

IMF (2014): World Economic Outlook October 2014, Washington, DC: International Monetary Fund.

Lucas, R. (1988): On the mechanics of economic development, in: Journal of Monetary Economics, 22(1), 3-42.

Mathieu, C., Sterdyniak, H. (2012): Revue de l'OFCE / Debates and policies, in: The Euro Area in Crisis, 127, 189-233.

Melo, P., Graham, D., Brage-Ardao, R. (2013): The productivity of transport infrastructure investment: a meta-analysis of empirical evidence, in: Regional Science and Urban Economics, 43, 695-706.

Musgrave, R.A. (1939): The nature of budgetary balance and the case for a capital budget, in: American Economic Review, 29, 260-271.

Musgrave, R.A. (1959): The Theory of Public Finance: A Study in Public Economy, New York: McGraw-Hill.

Psacharopoulos, G., Patrinos, H.A. (2004): Returns to investment in education: a further update, Education Economics, 12(2), 111-134.

Romp, W., De Haan, J. (2005): Public capital and economic growth: a critical survey, in: EIB Papers, 10, 40-71.

Sawyer, M. (2009): Budget deficits, public debt and the level of public investment, Departmental Working Papers 2009-31, Department of Economics, Management and Quantitative Methods at Università degli Studi di Milano.

SVR (Sachverständigenrat zur Begutachtung der gesamtwirtschaftlichen Entwicklung [German Council of Economic Experts]) (2007): Staatsverschuldung wirksam begrenzen, Expertise im Auftrag des Bundesministers für Wirtschaft und Technologie, Wiesbaden.

Truger, A. (2013): Austerity in the euro area: the sad state of economic policy in Germany and the EU, in: European Journal of Economics and Economic Policies: Intervention, 10(2), 158-174.

Truger, A. (2015a): Implementing the golden rule for public investment in Europe: safeguarding public investment and supporting the recovery, Working Paper, Reihe der AK Wien/Materialien zu Wirtschaft und Gesellschaft 138.

Truger, A. (2015b): Austerity, cyclical adjustment and the remaining leeway for expansionary fiscal policies within the current EU fiscal framework, IPE Working Paper No 50, Institute for International Political Economy Berlin.

Turrini, A. (2004): Public investment and the EU fiscal framework, European Economy Economic Papers 202, Directorate General Economic and Monetary Affairs, European Commission.

Välilä, T., Mehrotra, A. (2005): Evolution and determinants of public investment in Europe, in: EIB Papers, 10, 18-39.

Veugeleers, R. (2014): Undercutting the future? European research spending in times of consolidation, Bruegel Policy Contribution 06/2014. 